\title{
Study on the Impact of Corporation Social Responsibility on Financial Performance of Tourism Enterprises Based on the Regulatory Role of Corporate Strategy
}

\author{
Gege Zhang ${ }^{1, *}$ Huiyue Liu ${ }^{1}$
}

\begin{abstract}
${ }^{1}$ Shenzhen Tourism College, Jinan University, Shenzhen, Guangdong 518053, China
*Corresponding author. Email: zzhang_gg@126.com
\end{abstract}

\begin{abstract}
Based on the perspective of stakeholders, this paper selects the annual data of listed tourism companies from 2010 to 2018 as samples to study the correlation between corporate social responsibility (CSR) investment in tourism enterprises and corporate financial performance, and at the same time considers the regulatory role of corporate strategies. The results of empirical test show that when a company assumes all CSR, the assumption of shareholder responsibility will have a positive impact on its financial performance, and the company's sales intensity and cost-benefit strategy will also have a direct positive impact on its financial performance. The company's focus on cost-benefit strategy will exert a negative moderating effect on shareholders' responsibility and weaken its positive effect on financial performance. Therefore, enterprises should make it clear that different stakeholders have different needs. When enterprises choose different strategies at different stages of development, they can focus on different responsibilities in order to maintain a stable level of financial performance.
\end{abstract}

\section{Keywords: corporate social responsibility (CSR), corporate strategy, stakeholders, financial performance}

\section{INTRODUCTION}

In recent years, tourism has become a new engine of national economic growth, but there are still many contradictions in the development of this industry that need to be solved. For example, there are problems such as disorder in tourism management and frequently occurring phenomena of cheating and rip-offs; the discrepancy between growing tourism demand and lagging infrastructure construction; the overcrowded tourist destinations and increasing burden on the community environment; lack of talent in domestic tourism market, and surge on enterprise human capital and so on. In essence, these problems are reflected in the conflicts between tourism enterprises and stakeholders. From the perspective of stakeholders, enterprises should not only take the interests of shareholders as the ultimate goal, but should put the interests of shareholders in the same position as those of stakeholders (such as employees, consumers,

*Fund: This study is supported by the National Social Science Fund Project (14CJY004), the National Statistical Science Research Project (2017LZ13), the Guangdong Provincial Philosophy and Social Science Planning Project (GD19CLJ02), the Guangdong Provincial Soft Science Research Project (2019A101002021), and the Shenzhen Philosophy and Social Science Fund Project (SZ2019D010). customers, suppliers and environment, etc.). Most tourism enterprises believe that CSR investment will occupy corporate capital and other resources, increase additional costs and thus result in the reduction of financial performance. Driven by economic interests, tourism enterprises often neglect their social responsibilities. Based on the stakeholder theory, this paper studies the impact of corporate social responsibility on financial performance of China's tourism listed companies. Meanwhile, it considers the impact of corporate strategic positioning on corporate social responsibility performance and makes exploration by introducing corporate strategy as a regulatory variable.

\section{LITERATURE REVIEW}

\section{A. Concept definition}

The definition of corporate social responsibility was first proposed by Carroll (1979), which consists of four dimensions, namely economic responsibility, legal responsibility, ethical responsibility and charitable responsibility. Since then, many scholars have defined the concept of corporate social responsibility. Freeman (1990) believes that corporate social responsibility is composed of individuals or groups that influence or are 
influenced by the realization of corporate goals, and these individuals and groups constitute corporate stakeholders. In the follow-up study, Carroll (1991) deepens the concept of social responsibility by combining the four-dimensional social responsibility pyramid with the stakeholder theory, and believes that the realization of social responsibility should be considered from the perspective of enterprise stakeholders. Chinese scholars have also selected the perspective of stakeholders in their classic definition of social responsibility, believing that social responsibility can be divided into three levels: basic corporate social responsibility, intermediate corporate social responsibility and senior corporate social responsibility (Chen Xun, Han Yaqin, 2005). Based on tourism resources, the operation and development of tourism enterprises are characterized by strong comprehensiveness, large correlation and wide involvement. The paper identify the corporate social responsibility for tourism from the perspective of stakeholders, holding that the tourism enterprise is a symbiosis established by stakeholders on the basis of social capital, human resources, tourism resources and social environment and the investment and performance of social responsibility can balance the rights and interests of relevant stakeholders of the enterprise and realize the long-term goal of sustainable and balanced development of the enterprise. Based on this, the stakeholders in this paper are divided into internal stakeholders and external stakeholders. Among them, internal stakeholders are mainly based on the perspective of corporate governance structure, including shareholders and employees, while external stakeholders include consumers, customers, suppliers and the environment.

\section{B. Measurement of CSR investment}

Based on stakeholder theory and sustainable development theory, many scholars in China and abroad have selected different dimensions to measure CSR. The main ideas for measurement are as follows. The first is the selection of the corresponding theoretical basis or angle to construct the evaluation index system of corporate social responsibility. The second is empowerment. At present, the main methods of measuring index system include subjective empowerment, such as indistinct comprehensive evaluation method and Delphi method. Objective weighting methods include content analysis and factor analysis, etc. Early foreign studies emphasized the construction of reputation index to evaluate CSR from the perspective of social reputation (Bragdon and Marlin, 1972). Subsequently, the indicators of the social responsibility model are divided from internal and external criteria (Gallo, 2004). At present, it has become a mainstream research method to measure corporate social responsibility from the perspective of stakeholders (Maignan and Ralston, 2002; Luo Jiaqi,
Kuang Haibo, Shen Siyi, 2019). In the selection of measurement method, the indistinct comprehensive scoring method is mainly selected (Yan Shengyong, 2007; Fu Shuke, et al., 2014), content analysis (Hu Bing, Li Ting, Wen Tong, 2018), factor analysis (Ye Chengang, et al., 2013). To sum up, the stakeholder theory enriches the connotation of corporate social responsibility and clarifies the object of corporate social responsibility. If an enterprise is to achieve sustainable development, it should maintain long-term cooperation with various stakeholders and balance the interests of stakeholders. Therefore, in the process of measuring the social responsibility of tourism enterprises, this paper also chooses the perspective of stakeholders to construct the evaluation index system.

\section{Research on the relationship between CSR investment and economic benefit}

With the deepening of the research on corporate social responsibility (CSR), researches on the effectiveness of CSR investment in economic benefits are increasing. As for the correlation between CSR and economic benefits, it can be divided into three perspectives: CSR input is positively correlated with economic benefits; there is a negative correlation between CSR investment and economic benefit; there is no correlation between enterprises' fulfillment of social responsibility and the increase or decrease of economic benefit, that is, the input of social responsibility is invalid from the perspective of economic benefit. There is no unanimous conclusion in the empirical research of foreign scholars. Griffin and Mahon (1997) collated a total of 51 research results from 1972 to 1994, among which 33 showed positive correlation, 19 negative correlation, and 9 no correlation. These three different viewpoints have still been in relevant studies after the 1990s (Brammer, et al., 2006; Dijken, 2007; Li Qian, Xiong Jie, Huang Han, 2018; Siueia, Wang and Deladem, 2019). Due to the lack of social responsibility exposed by the tourism enterprises is increasingly prominent, many scholars have also put the research scope of effectiveness of CSR investment in economic benefits from the whole market narrowed down to tourism enterprises and through empirical test, come to the main conclusion that corporate social responsibility and financial performance is positive correlated ( $\mathrm{Li}$ Wuwu, Mr. Wong, 2013; Wang Caiping, et al., 2015).

\section{RESEARCH DESIGN}

\section{A. Research hypothesis}

According to the literature review, the mainstream view is that there is a positive correlation between corporate social responsibility and financial performance of tourism listed companies. Based on the stakeholder management model and aiming at the relationship between corporate social responsibility, 
corporate strategy and corporate financial performance of tourism listed companies, this paper proposes the following two hypotheses.

H1: Corporate social responsibility and corporate strategy of tourism listed companies have direct and separate influences on corporate financial performance.

$\mathrm{H} 2$ : The relationship between corporate social responsibility and corporate financial performance of tourism listed companies will be influenced by the adjustment of corporate strategy.

\section{B. Data sources and variable definitions}

In this study, 41 listed companies in the tourism industry in Shanghai and Shenzhen from 2010 to 2018 were selected. In order to ensure the validity of the data, special treatment stocks were excluded, including two enterprises, Cloud Live Technology and ST Tibet Tourism. Finally, a total of 39 sample enterprises were selected, with data from the Corporate Social Responsibility Database of Hexun.com and the
CSMAR databases. Some indicators were obtained through manual sorting. There are mainly three types of analytical variables used in the empirical analysis in this paper: the explained variable is the return on assets ( $R O A)$; the explanatory variables are corporate strategy ( STR ) and corporate social responsibility ( $C S R$ ), in which corporate strategy is represented by sales intensity $(S I)$ and cost-effectiveness ( $E F$ ); corporate social responsibility includes multiple variables such as shareholders ( $S H A$ ), employees ( $E M P$ ), suppliers, customers and consumers ( $S U P$ ), environment $(E N V)$ and social responsibility $(S O C$ ), etc. Since the rate of return on assets is affected by many aspects, in order to improve the accuracy of the study, this paper introduces a group of factors of the company's operating environment $(O E)$ as control variables, mainly including environmental laxity ( $M U$ ), environmental dynamics ( $D Y$ ) and environmental forces $(P U)$. Variables and their associated definitions are shown in "Table I".

TABLE I. VARIABLES AND THEIR ASSOCIATED DEFINITIONS

\begin{tabular}{|c|c|c|c|}
\hline Variable category & \multicolumn{2}{|c|}{ Variable name } & Variable definition \\
\hline Explained variable & \multicolumn{2}{|l|}{ Return on assets ( $R O A)$} & The ratio of net profit to total assets \\
\hline \multirow{7}{*}{ Explaining variable } & \multirow{5}{*}{$\begin{array}{l}\text { Enterprise } \quad \text { social } \\
\text { responsibility }(C S R)\end{array}$} & Shareholders' responsibility ( $S H A$ ) & $\begin{array}{l}\text { The company's responsibility to shareholders is } \\
\text { presented in the form of score }\end{array}$ \\
\hline & & Employee responsibilities ( $E M P$ ) & $\begin{array}{l}\text { The company's responsibility to its employees is } \\
\text { presented in the form of score }\end{array}$ \\
\hline & & $\begin{array}{l}\text { Rights and interests of suppliers, } \\
\text { customers and consumers ( } S U P)\end{array}$ & $\begin{array}{l}\text { The rights and interests of suppliers, customers } \\
\text { and consumers assumed by the company shall be } \\
\text { displayed in the form of score }\end{array}$ \\
\hline & & Environmental responsibility ( $E N V)$ & $\begin{array}{l}\text { The environmental responsibility of the company } \\
\text { is presented in the form of score }\end{array}$ \\
\hline & & Social responsibility ( $S O C$ ) & $\begin{array}{l}\text { The company's responsibility to society is } \\
\text { presented in the form of score }\end{array}$ \\
\hline & \multirow{2}{*}{$\begin{array}{l}\text { Corporate } \\
(S T R)\end{array}$} & Sales intensity $(S I)$ & $\begin{array}{l}\text { The ratio of sales and administrative expenses to } \\
\text { total assets }\end{array}$ \\
\hline & & Cost-effectiveness ( $E F$ ) & $\begin{array}{l}\text { The ratio of cost of service and sales to revenue } \\
\text { from sales }\end{array}$ \\
\hline \multirow{5}{*}{ Control variable } & \multirow{3}{*}{$\begin{array}{l}\text { Operation environment } \\
(O E)\end{array}$} & Environmental laxity $(M U)$ & $\begin{array}{l}\text { The slope of total industry sales revenue based } \\
\text { on the rolling window }\end{array}$ \\
\hline & & Environmental dynamism ( $D Y$ ) & $\begin{array}{l}\text { Calculating the ratio of regression standard } \\
\text { deviation of environmental laxity to industry } \\
\text { average sales revenue }\end{array}$ \\
\hline & & Environmental forces $(P O)$ & $\begin{array}{l}\text { The ratio between the sum of sales revenue of the } \\
\text { top four companies and the total sales revenue of } \\
\text { the industry based on the rolling window }\end{array}$ \\
\hline & \multirow{2}{*}{$\begin{array}{l}\text { Enterprise characteristic } \\
(E C)\end{array}$} & Enterprise scale ( $S I Z E$ ) & The natural $\log$ of the total assets of an enterprise \\
\hline & & Enterprise age ( $A G E$ ) & Listed years of the listed tourism companies \\
\hline
\end{tabular}

According to the research hypothesis and variables, the model was constructed as follows:

$$
\begin{aligned}
& \operatorname{ROA}_{i, t}=\alpha_{0}+\beta_{1} \text { STR }_{i, t}+\beta_{2} \text { Controls }+\varepsilon_{i, t}(1) \\
& \operatorname{ROA}_{i, t}=\alpha_{0}+\beta_{1} \operatorname{STR}_{i, t}+\beta_{2} \text { CSR }_{i, t}+\beta_{3} \text { Controls }+\varepsilon_{i, t}(2) \\
& \operatorname{ROA}_{i, t}=\alpha_{0}+\beta_{1} \text { STR }_{i, t}+\beta_{2} \text { CSR }_{i, t}+\beta_{3} \text { STR }_{i, t} \times \text { CSR }_{i, t}+\beta_{4} \text { Controls }+\varepsilon_{i, t}
\end{aligned}
$$


In the formulas, $R O A_{i, t}$ represents the net interest rate of corporate $i$ in the year $t, \alpha$ is the constant term, $\beta$ represents the coefficient value of each variable, ${ }_{i}$ is the section unit of each corporate, ${ }^{t}$ represents the year and $\mathcal{E}$ is the stochastic error term.

\section{EMPIRICAL STUDY}

\section{A. Descriptive analysis}

As can be seen from "Table II", the return on assets ( $R O A)$ of tourism listed companies has a maximum value of $31.6 \%$ and a minimum value of $-50.9 \%$, indicating that there is a big difference in financial performance of tourism listed companies, with an average value of $4.1 \%$, and that the overall level of industry profits is low. Corporate strategy variables ( $S I$ and $E F$ ) also have a smaller standard deviation, showing their strong stability and representativeness. The standard deviation of corporate social responsibility variables ( $S H A, E M P, S U P, E N V$ and $S O C$ ) is large, indicating that different listed tourism companies have great differences in the performance of social responsibility. Among them, the minimum values of shareholder responsibility ( $S H A$ ) and social responsibility ( $S O C$ ) are both negative, indicating that some enterprises perform poorly in terms of shareholder responsibility and social responsibility; the minimum values of employee responsibility (EMP), supplier, customer and consumer rights and interests responsibility ( SUP) and environmental responsibility $(E N V)$ are all 0, indicating that some corporates fail to disclose relevant information. The overall standard deviation of the control variables operating environment ( $M U, D Y$ and $P O$ ) is not large, indicating that the overall operating environment of the corporate from 2010 to 2018 is similar. In addition, since some enterprises went public after 2010, the age of listing of enterprises ( $A G E$ ) is negative. From the perspective of enterprise scale, since (SIZE) is the value of the natural logarithm of the total assets of an corporate, it weakens the difference in corporate scale, but it can still be seen that there are some differences in the scale of each tourism corporate.

TABLE II. DESCRIPTIVE STATISTICAL ANALYSIS OF VARIABLES

\begin{tabular}{|c|c|c|c|c|c|}
\hline Variables & Sample size & Mean value & Standard deviation & Minimum value & Maximum value \\
\hline ROA & 351 & 0.041 & 0.055 & -0.509 & 0.316 \\
\hline EF & 351 & 0.612 & 0.233 & 0.000 & 1.062 \\
\hline DY & 351 & 0.683 & 0.263 & 0.287 & 1.080 \\
\hline $\mathrm{PO}$ & 351 & 0.723 & 0.040 & 0.659 & 0.774 \\
\hline SHA & 351 & 14.180 & 5.714 & -6.710 & 23.810 \\
\hline ENV & 351 & 1.704 & 4.167 & 0.000 & 15.000 \\
\hline SOC & 351 & 7.894 & 3.997 & -10.000 & 18.790 \\
\hline AGE & 351 & 14.737 & 6.077 & -0.170 & 26.730 \\
\hline SIZE & 351 & 22.250 & 1.785 & 18.287 & 26.407 \\
\hline Number of ID & 39 & 39 & 39 & 39 & 39 \\
\hline
\end{tabular}

\section{B. Model estimation result}

Stata14 software was used for regression of the model, and the regression results are shown in "Table III". Model 1 mainly includes independent variables corporate strategy ( $S I, E F$ ) and various control variables. According to the regression results, the sales intensity ( $S I$ ) is significantly positive at the confidence level of 0.01 , and the financial indicators $R O A$ of the enterprise ill increase by 0.119 units for every unit increase in sales intensity input. The coefficient of costbenefit $(E F)$ is negative, but the result is not significant. The two independent variables of the corporate strategy and the enterprise social responsibility and the control variables are incorporated into Model 2. Compared with model 1, the regression coefficient of sales strength SI increased by 0.066 , which had a more significant positive impact on the financial performance of the enterprise. Although the cost-benefit EF regression coefficient increased by 0.011 , the impact on financial performance was still not significant. Among the variables of corporate social responsibility ( $C S R$ ), shareholder responsibility ( $S H A$ ) is significantly positive at the confidence level of 0.01. For every unit increase of shareholder responsibility input, enterprise performance ( $R O A$ ) will increase by 0.006 units. Model 1 and model 2 jointly point out that corporate strategy and corporate social responsibility have direct and separate influences on corporate financial performance, and hypothesis $\mathrm{H} 1$ is verified. (See "Table III") 
TABLE III. REGRESSION RESULTS OF SOCIAL RESPONSIBILITY AND FINANCIAL PERFORMANCE

\begin{tabular}{|c|c|c|c|c|}
\hline Variables & Model1 & Model 2 & Model 3 & Model 4 \\
\hline \multirow[t]{2}{*}{ SI } & $0.119 * * *$ & $0.185 * * *$ & $0.170 * * *$ & $0.278^{* *}$ \\
\hline & $(0.045)$ & $(0.056)$ & $(0.055)$ & $(0.139)$ \\
\hline \multirow[t]{2}{*}{$E F$} & -0.001 & 0.010 & $0.110 * * *$ & 0.007 \\
\hline & $(0.018)$ & $(0.022)$ & $(0.039)$ & $(0.023)$ \\
\hline \multirow[t]{2}{*}{ SHA } & & $0.006^{* * * *}$ & $0.012 * * *$ & $0.006^{* * * *}$ \\
\hline & & $(0.001)$ & $(0.002)$ & $(0.001)$ \\
\hline \multirow[t]{2}{*}{ EMP } & & -0.003 & -0.007 & -0.001 \\
\hline & & $(0.004)$ & $(0.010)$ & $(0.005)$ \\
\hline \multirow[t]{2}{*}{ SUP } & & 0.000 & 0.005 & -0.000 \\
\hline & & $(0.002)$ & $(0.008)$ & $(0.003)$ \\
\hline \multirow[t]{2}{*}{$E N V$} & & 0.001 & -0.002 & -0.000 \\
\hline & & $(0.002)$ & $(0.012)$ & $(0.004)$ \\
\hline \multirow[t]{2}{*}{$S O C$} & & -0.000 & -0.002 & 0.001 \\
\hline & & $(0.001)$ & $(0.002)$ & $(0.001)$ \\
\hline \multirow[t]{2}{*}{ EFSHA } & & & $-0.010^{* * *}$ & \\
\hline & & & $(0.003)$ & \\
\hline \multirow[t]{2}{*}{ EFEMP } & & & 0.006 & \\
\hline & & & $(0.014)$ & \\
\hline \multirow[t]{2}{*}{ EFSUP } & & & -0.007 & \\
\hline & & & $(0.012)$ & \\
\hline \multirow[t]{2}{*}{ EFENV } & & & 0.004 & \\
\hline & & & $(0.016)$ & \\
\hline \multirow[t]{2}{*}{ EFSOC } & & & 0.003 & \\
\hline & & & $(0.003)$ & \\
\hline \multirow[t]{2}{*}{ SISHA } & & & & 0.002 \\
\hline & & & & $(0.007)$ \\
\hline \multirow[t]{2}{*}{ SIEMP } & & & & -0.034 \\
\hline & & & & $(0.038)$ \\
\hline \multirow[t]{2}{*}{ SISUP } & & & & -0.001 \\
\hline & & & & $(0.051)$ \\
\hline \multirow[t]{2}{*}{ SIENV } & & & & 0.022 \\
\hline & & & & $(0.079)$ \\
\hline \multirow[t]{2}{*}{ SISOC } & & & & -0.008 \\
\hline & & & & $(0.011)$ \\
\hline \multirow[t]{2}{*}{$M U$} & $1.353 * *$ & 0.460 & 0.371 & 0.438 \\
\hline & $(0.604)$ & $(0.581)$ & $(0.570)$ & $(0.586)$ \\
\hline \multirow[t]{2}{*}{$D Y$} & $-0.449 * *$ & -0.169 & -0.142 & -0.161 \\
\hline & $(0.197)$ & $(0.189)$ & $(0.185)$ & $(0.191)$ \\
\hline \multirow[t]{2}{*}{$P O$} & $0.199 * *$ & $-0.506^{*}$ & -0.406 & $-0.529 *$ \\
\hline & $(0.098)$ & $(0.296)$ & $(0.291)$ & $(0.299)$ \\
\hline \multirow[t]{2}{*}{ SIZE } & $0.005^{*}$ & -0.002 & -0.002 & -0.002 \\
\hline & $(0.003)$ & $(0.006)$ & $(0.006)$ & $(0.006)$ \\
\hline \multirow[t]{2}{*}{$A G E$} & $-0.002 * *$ & $-0.012 * * *$ & $-0.011^{* *}$ & $-0.012 * * *$ \\
\hline & $(0.001)$ & $(0.004)$ & $(0.004)$ & $(0.004)$ \\
\hline Constant & $-0.441 * *$ & 0.451 & 0.323 & 0.462 \\
\hline & $(0.185)$ & $(0.368)$ & $(0.362)$ & $(0.372)$ \\
\hline Observations & 351 & 351 & 351 & 351 \\
\hline$R$-squared & 0.116 & 0.322 & 0.366 & 0.326 \\
\hline Number of id & 39 & 39 & 39 & 39 \\
\hline
\end{tabular}

In model 3 and model 4, the interaction items of sales intensity ( $S I$ ) and corporate social responsibility ( $C S R$ ), as well as cost-effectiveness ( $E F$ ) and corporate social responsibility ( $C S R$ ) were added to carry out regression. As can be seen from model 3 , the interaction coefficient between cost-benefit and shareholder responsibility is negative, that is, costbenefit has a negative moderating effect on shareholder responsibility. This indicates that enterprises' cost- effectiveness weakens the positive impact of shareholders' responsibility on financial performance, which may be because more cost expenditure will make shareholders think that the company's profit will be reduced, thus inhibiting financial performance. As can be seen from model 4 , the interaction coefficient between sales intensity and shareholder responsibility is positive, but the regression result is not significant, that is, there is a positive adjustment effect, but the effect is not obvious. At this point, the influence coefficient of 
sales intensity on financial performance increases by 0.1 units. To sum up, the company strategy has a moderating effect, and $\mathrm{H} 2$ is assumed to be established.

\section{CONCLUSION}

This paper takes 39 listed tourism enterprises in China from 2010 to 2018 as samples to explore the impact of CSR investment on financial performance under the adjustment of corporate strategy. The following conclusions are drawn: the fulfillment of corporate social responsibility and the formulation of corporate strategy have a direct and separate impact on corporate financial performance. The increase of sales input and product cost input has a positive impact on enterprise financial performance. When enterprises attach importance to cost-effectiveness, the increase of input in product cost will weaken the positive impact of shareholder responsibility on financial performance. This is because the focus of shareholders on the enterprise is only on the profit. The profit of the enterprise is carried over to the owner's equity and then distributed to shareholders through dividends. The increase of cost means the decrease of profit, that is, the decrease of shareholders' income, so the impact of shareholders' responsibility on financial performance will be weakened. Emphasis on cost efficiency will also increase the negative influence of social responsibility on financial performance, because the higher cost input to some extent reflects the higher requirements of enterprises for their own image. These enterprises are also likely to carry out some activities that are beneficial to the public to maintain their corporate image. However, when enterprises assume their social responsibilities, they will inevitably invest more funds, which will have a negative impact on their financial performance.

Based on the above research results, this paper proposes the following suggestions. Enterprises should clear the different stakeholder's role in the process of enterprise development. When enterprise undertakes the responsibilities of shareholders, employees, suppliers, customers and consumers, environmental responsibilities and social responsibilities simultaneously, it should increase the performance of the responsibilities of shareholders. Since the shareholders may pay more attention to the short-term profitability of the enterprise, yet the society has a greater pursuit for the quality of products and the image of the enterprise, the corporate social responsibility to the shareholders will significantly affect the current financial performance of the enterprise. Different development strategies adopted by enterprises will also have different impacts on enterprises. When enterprises increase their willingness to spend on marketing and sales activities, shareholders will have a positive response to this. At this time, enterprises can maintain a high level of financial performance without too much investment in the responsibilities of shareholders. However, when enterprises attach importance to the cost input of products and services, they need to invest more in the responsibility of shareholders, such as paying more dividends and paying more attention to product innovation, so as to maintain the original level of financial performance. In addition, the increase of investment in product and service costs will lead to a greater decline in financial performance of a unit in fulfilling its social responsibility. Therefore, enterprises should pay close attention to the fulfillment of their social responsibility at this time, for example, reducing public donations to prevent a significant decrease in financial performance.

\section{References}

[1] Chen Xun, Han Yaqin. Hierarchical Model and Application of Enterprise Social Responsibility [J]. China Industrial Economy, 2005 (9): 99-105. (in Chinese)

[2] Fu Shuke, Yang Shuwang, Tang Pengcheng, et al. Social Responsibility Evaluation of China's Nonferrous Metal Industry — Data from Listed Enterprises [J]. Macroeconomics, 2014 (4) 18-26. (in Chinese)

[3] Hu Bing, Li Ting, Wen Tong. Structural Dimensions and Model Construction of Social Responsibility of Listed Tourism Enterprises - an Exploratory Study Based on Grounded Theory [J]. Tourism Tribune, 33 (10): 37-46. (in Chinese)

[4] Li Qian, Xiong Jie, Huang Han. An Empirical Research of Corporate Social Irresponsibility on Financial Performance [J] Chinese Journal of Management, 2008,15 (02): 255-261. (in Chinese)

[5] Li Wuwu, Wang Jing. A Study on the Relationship between Tourism Corporation Social Responsibility of and Operation Efficiency [J]. Tourism Tribune, 2013, 03 (28): 47-51. (in Chinese)

[6] Luo Jiaqi, Kuang Haibo, Shen Siyi. Impact of corporate social responsibility on financial performance by taking the transportation industry as an example [J]. Science Research Management, 2019, 40 (02): 201-210. (in Chinese)

[7] Wang Caiping, Bai Binyao, $\mathrm{Xu}$ Honggang. Influences of Corporate Social Responsibility on Sustainable Operation of Small Tourism Enterprises Located at Heritage Sites in China [J]. Journal of tourism, 2015, (09): 25-33. (in Chinese)

[8] Yan Shengyong. On the Integrated Financial Evaluation on Listed Company's Social Responsibilities [J]. Finance \& Economics, 2007 (4): 66-72. (in Chinese)

[9] Ye Chengang, Wang Zi. Corporate Social Responsibility Performance Evaluation and Market Response [J]. Soft Science, 2013, 27 (06): 1-5 + 14. (in Chinese)

[10] Bragdon J H, Marlin J T. Is pollution profitable? [J]. Risk Management, 1972, 19(4): 9-18.

[11] Brammer S, Brooks C, Pavelin S. Corporate social performance and stock returns: UK evidence from disaggregate measures [J]. Financial Management, 2006, 35(3): 97-116.

[12] Carroll A B. A three-dimensional conceptual model of corporate performance [J]. Academy of Management Review, 1979, 4(4): 497-505.

[13] Carroll A B. The pyramid of corporate social responsibility: Toward the moral management of organizational stakeholders [J]. Business Horizons, 1991, 34(4): 39-48. 
[14] Dijken F V. Corporate social responsibility: Market regulation and the evidence [J]. Managerial Law, 2007, 49(4): 141-184.

[15] Freeman R. Strategic management: A stakeholder approach [J]. Cambridge University Press, 1984.

[16] Gallo M A. The family business and its social responsibilities [J]. Family Business Review, 2004, 17(2):135-149.

[17] Griffin J J, Mahon J F. The corporate social performance and corporate financial performance debate: Twenty-five years of incomparable research [J]. Business \& Society: Founded at Roosevelt University, 1997, 36(1): 5-31.

[18] ISO, ISO 26000:2010 (2010), Guidance on social responsibility, International Organization for Standardization, Geneva.

[19] Maignan I, Ralston D A. Corporate social responsibility in europe and the U.S.: Insights from businesses' selfpresentations [J]. Journal of International Business Studies, 2002, 33(3): 497-514.

[20] Siueia $\mathrm{T}$ T, Wang J, Deladem $\mathrm{T}$ G. Corporate Social Responsibility and financial performance: A comparative study in the Sub-Saharan Africa banking sector [J]. Journal of Cleaner Production, 2019, 226: 658-668 